\title{
Increased levels of surfactant protein A and D in bronchoalveolar lavage fluids in patients with bronchial asthma
}

\author{
G. Cheng*, T. Ueda*, T. Numao*, Y. Kuroki**, H. Nakajima*, Y. Fukushima*, \\ S. Motojima\#, T. Fukuda*
}

Increased levels of surfactant protein $A$ and $D$ in bronchoalveolar lavage fluids in patients with bronchial asthma. G. Cheng, T. Ueda, T. Numao, Y. Kuroki, H. Nakajima, Y. Fukushima, S. Motojima, T. Fukuda. (C)ERS Journals Ltd 2000

ABSTRACT: Surfactant proteins (SP)-A and SP-D are collagen-like glycoproteins belonging to the "collectin" class of C-type lectins, which are primarily synthesized in type II cells. Recent studies reported the possibility of local production of SP-A and SP-D in the airways, but the amounts of surfactant proteins in patients with bronchial asthma have not been studied.

The composition of surfactant proteins in mild, stable asthmatics in the first lavage as bronchial lavage (BL) and the second and third lavages consecutively as alveolar lavages (AL) were therefore, analysed separately. The co-relationships in the BL between the amounts of surfactant proteins and those of fucose, which is one of the markers of submucosal secretion were also analysed.

Increased amounts of SP-A in BL and AL of in asthmatics were found as compared with those in controls. A high concentration of SP-D in the AL asthma patients was also found. The levels of SP-A correlated with those of fucose in patients with bronchial asthma $(r=0.849, p<0.01)$.

The observations in the present study suggested that surfactant protein A may be secreted from the airways with allergic inflammation in a different manner from the alveoli. The increased levels of surfactant proteins $A$ and $D$ may play a protective role in an allergic inflammation in the pathogenesis of bronchial asthma.

Eur Respir J 2000; 16: 831-835.
*Dept of Internal Medicine and Clinical Immunology, Dokkyo University School of Medicine, Tochigi, Japan. **Dept of Biochemistry, Sapporo Medical College, Hokkaido, Japan. " Kameda Medical Center, Chiba, Japan.

Correspondence: G. Cheng

Dept of Internal Medicine and Clinical Immunology

Mibu-machi

Shimotsuga-gun

Tochigi, 321-0293

Japan

Fax: 81282865080

Keywords: Asthma surfactant protein A surfactant protein D

Received: November 221999

Accepted after revision July 212000
A pulmonary surfactant is a highly surface-active material, which prevents alveolar collapse by reducing surface tensions at the air-liquid interface in alveolar spaces. Although this concept is widely accepted, surfactants are rapidly expanding their list of properties. Several recent studies indicated that surfactants also play a significant role in the patency of small airways. Increased airway resistance in asthma could be partially due to a surfactant dysfunction [1]. KURASHIMA et al. [2] reported that in adult asthmatics nebulization of artificial surfactant (surfactant-TA) resulted in a dramatic improvement in the vital capacity (VC) and forced expiratory volume in one second (FEV1). Recently impairment of surfactant function has been reported in asthmatics and animal models of asthma [3, 4], but changes in the composition of surfactants in asthmatics have not been studied extensively.

Surfactant protein (SP)-A and SP-D are collagen-like glycoproteins belonging to the "collectin" class of C-type lectins that may play an important role in pulmonary host defence $[5,6]$. Surfactants are believed to be primarily synthesized and stored in type II cells and secreted into the alveolar spaces. Although pulmonary surfactant like materials exist in the airways as well as in the alveolar region, the origin of the airway surfactant is still controversial [7]. Wong et al. [8] recently reported that SP-D and SP-A messenger ribonucleic acid (mRNA) and protein were detected by in situ hybridization and immunocytochemistry in alveolar type II and nonciliated bronchiolar epithelial cells of the lungs, as well as in cells of the tracheal epithelium and tracheal submucosal glands of the adult mouse. More recently, SAITo et al. [9] also reported that airway submucosal glands express and secrete SP-A2 alone, but not SP-A1, SP-B, SP-C or SP-D. Therefore, the authors asked firstly whether the levels of surfactant associated proteins in the bronchoalveolar lavage (BAL) fluid would be altered in patients with bronchial asthma. To answer the question for local production of surfactant proteins in the airways, the composition of surfactant proteins in the first lavage as bronchial lavage (BL) and the second and third lavages consecutively as alveolar lavages (AL) were investigated separately $[10,11]$. The co-relationships in the BL between the amounts of surfactant proteins and those of fucose, which is thought to be one of the markers of submucosal secretion were also analysed.

\section{Materials and methods}

Subjects

Surfactant analysis was performed on aliquots of alveolar lavage material obtained from patients who underwent fibreoptic bronchoscopy for various diagnostic indications. The results for ten patients (the ages ranged 21-64 yrs; median age, 42 yrs) with an established diagnosis of bronchial asthma, (seven patients, atopic; three patients, nonatopic) were compared with those from 11 
patients without bronchial asthma (range, 18-72 yrs; median age $44 \mathrm{yrs}$, seven patients with cough, four patients with solitary nodules in chest radiographs). All of the asthmatic subjects were in a stable condition and had no other pulmonary disease. The classification of asthma severity was mild in this study. At the time of enrolement, all the asthmatic subjects had a stable pulmonary function, with a baseline FEV $1 \geq 70 \%$ of that predicted for their age and height.

All of the subjects were nonsmokers and had not received oral corticosteroids or inhaled corticosteroids within the preceding 2 months. Asthmatic subjects were treated with $\beta_{2}$-sympathicomimetic agents on request. All the subjects had been free of acute respiratory tract infections within the preceding 2 months. The study conformed to the Declaration of Helsinki; and informed written consent was obtained from each subject. Pulmonary function tests were performed at least 7 days before fibreoptic bronchoscopy. All patients without bronchial asthma had normal pulmonary function tests, including diffusing capacity before bronchoscopy. Other than the solitary nodules present on the chest radiographs of four patients in this group, there was no evidence of diffuse lung parenchymal damage in any of these patients.

\section{Alveolar lavage technique}

Bronchoscopy was performed in the awake, spontaneously breathing state with topical xylocaine anaesthesia. After the bronchoscope was wedged into the right middle lobe, $50 \mathrm{~mL}$ sterile saline $\left(37^{\circ} \mathrm{C}\right)$ was instilled through the scope, followed by gentle suction to recover lavage material. This procedure was repeated three times, and each recovered lavage volume was recorded.

\section{Surfactant analysis}

Aliquots of $\mathrm{BL}$ and $\mathrm{AL}$ were analysed separately. Alveolar washes were used for the determination of phospholipid concentrations according to the method of BARTLETT [12]. The latter assay is based on phosphorus determination carried out on the lipid, previously extracted with chloroform/methanol according to BLIGH
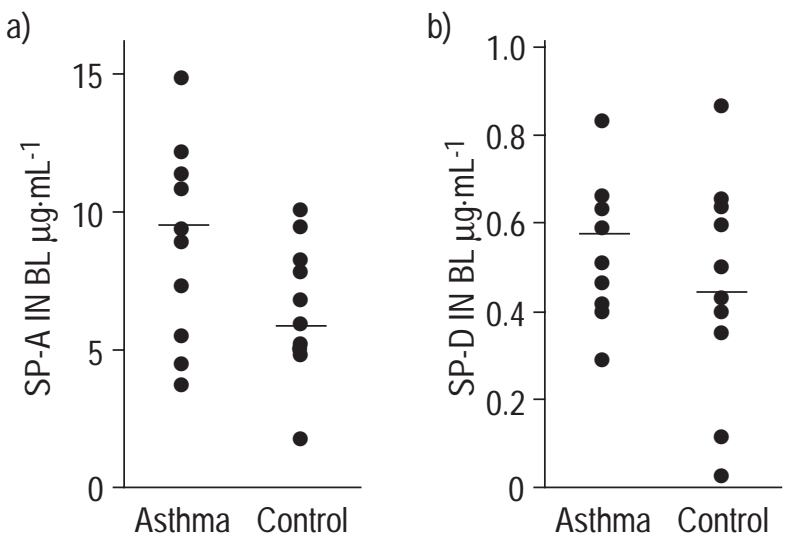

and DYER [13]. To determine the saturated phosphatidylcholine (SAT-PC) pool size, aliquots of alveolar washes were extracted by the BLIGH and DYER [13] method and treated with osmium tetroxide [14], and the quantity of SAT-PC was recovered from alumina columns measured by the phosphorus assay [12]. Monoclonal antibodies were prepared against human SP-A, and enzyme-linked immunosorbent assay (ELISA) for its determination was performed with solid-phase monoclonal antibody PC6 and HRP-conjugated monoclonal antibody PE10 as described previously [15]. This assay system was able to detect SP-A at $2.0-250 \mathrm{ng} \cdot \mathrm{mL}^{-1}$. The human SP-D was also measured by sandwich ELISA with monoclonal antibody 7C6 and HRP-conjugated monoclonal antibody 6B2 as previously described [16]. This assay made it possible to determine the concentration of human SP-D ranging 3.13-200 $\mathrm{ng} \cdot \mathrm{mL}^{-1}$. The amount of total protein was measured by the method of LowRY et al. [17]. The quantity of fucose in the alveolar washes was measured by Winzler's method [18].

\section{Statistical analysis}

Data were expressed as mean \pm SEM. The Mann-Whitney $\mathrm{U}$ test was applied to the data analyses for assessing the differences between control subjects and patients with asthma. SP-A concentrations in BL were regressed linearly against fucose concentrations by the least squares method. Significance was accepted at $\mathrm{p}<0.05$.

\section{Results}

Bronchoscopy with BAL was performed successfully and was well tolerated in all subjects. There was no difference between the total recovery rate for asthmatics $(59.1 \pm 2.9 \%)$ and control subjects $(56.9 \pm 1.8 \%)$. The recovery rates of the BL were also similar for both groups (38.8 $\pm 4.7 \%$ in asthmatics and $36.7 \pm 3.0 \%$ in controls).

The concentrations of SP-A, SP-D and total phospholipid, SAT-PC in BL from each sample were plotted as shown in figure 1 . The mean value of the SP-A concentration in asthmatics $\left(9.3 \pm 1.0 \mathrm{mg} \cdot \mathrm{mL}^{-1}\right)$ was significantly higher than that in controls $\left(6.4 \pm 0.7 \mathrm{mg} \cdot \mathrm{mL}^{-1}\right.$, c)

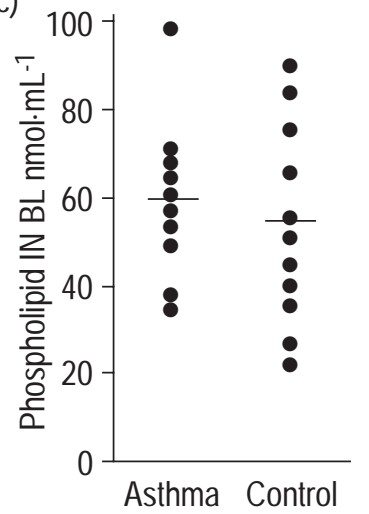

d)

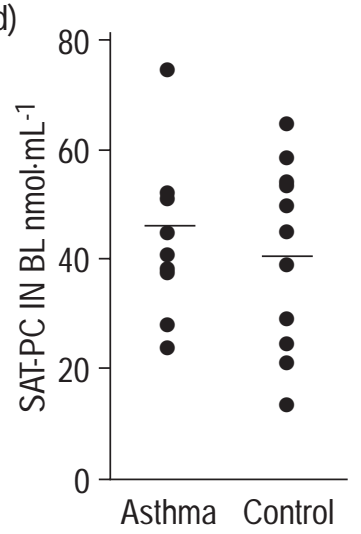

Fig. 1. - The concentrations of a) SP-A, b) SP-D, c) total phospholipid and d) saturated phosphatidylcholine (SAT-PC) in bronchial lavages (BL). Data are presented as mean \pm SEM. $\mathrm{p}<0.05$ for (a) and was not significant for (b), (c) and (d). SP-A: surfactant protein A; BL: bronchoalveolar lavage; SPD: surfactant protein D; SAT-PC: saturated phosphatidylcholine. Horizontal bars represent mean values. 

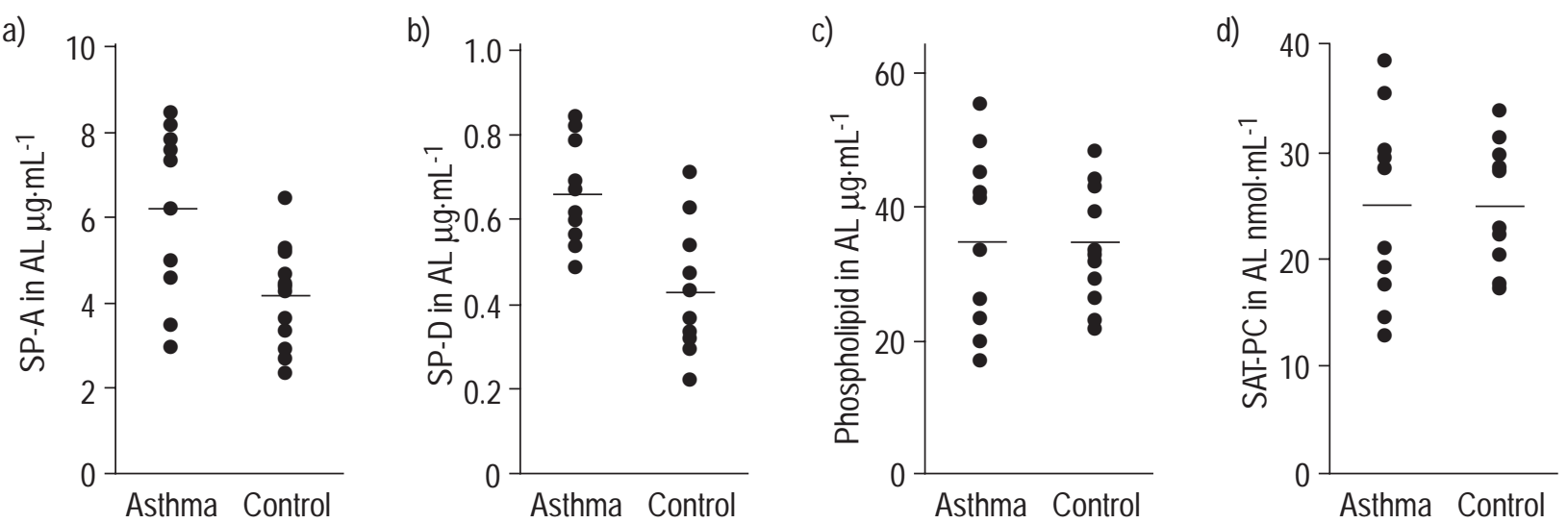

Fig. 2. - The concentrations of a) surfactant protein A (SP)-A, b) surfactant protein (SP)-D, c) phospholipid and d) saturated phosphatidylcholine (SAT$\mathrm{PC}$ ) in alveolar lavages (AL). $\mathrm{p}<0.05$ for $(\mathrm{a}), \mathrm{p}<0.01$ for (b) and was not significant for (c) and (d). Horizontal bars represent mean values.

$\mathrm{p}<0.05$, (fig. 1a)), whereas the SP-D concentration in BL of asthmatics was similar to that in controls $(0.56 \pm 0.04$ $\mathrm{mg} \cdot \mathrm{mL}^{-1}$ in asthmatics, $0.45 \pm 0.07 \mathrm{mg} \cdot \mathrm{mL}^{-1}$ in controls, (fig. 1b)). As shown in figure 1c the total phospholipid concentration from asthmatics $\left(60 \pm 5.3 \mathrm{nmol} \cdot \mathrm{mL}^{-1}\right)$ was not significantly different when compared to the controls $\left(54 \pm 7.6 \mathrm{nmol} \cdot \mathrm{mL}^{-1}\right)$. The mean SAT-PC concentration in BL fluid of asthmatics $\left(45 \pm 4 \mathrm{nmol} \cdot \mathrm{mL}^{-1}\right)$ and controls $\left(41 \pm 5 \mathrm{nmol} \cdot \mathrm{mL}^{-1}\right)$ was similar (fig. 1d).

The concentration of SP-A, SP-D, and total phospholipid, SAT-PC in AL from each sample is shown in figure 2. The SP-A concentration in asthmatics was higher than that in controls $\left(6.1 \pm 0.8 \mathrm{mg} \cdot \mathrm{mL}^{-1}\right.$ versus $\left.4.4 \pm 0.5 \mathrm{mg} \cdot \mathrm{mL}^{-1}, \mathrm{p}<0.05\right)$. The SP-D concentration in AL of asthmatics was also higher than that in controls $\left(0.62 \pm 0.04 \mathrm{mg} \cdot \mathrm{mL}^{-1}\right.$ versus $\left.0.42 \pm 0.06 \mathrm{mg} \cdot \mathrm{mL}^{-1} ; \mathrm{p}<0.01\right)$. The levels of total phospholipid and SAT-PC in AL were similar in the two groups. Total protein in both BL and $\mathrm{AL}$ was increased in the asthmatics when compared to the control groups (data not shown).

The ratio of SP-A to SAT-PC in BL was also higher in asthmatics than in controls $(p<0.05$, fig. $3 a)$. The ratios of SP-A and SP-D to SAT-PC in AL of asthmatics was higher than that in controls $(p<0.05$, fig $3 b, c)$.

The correlation between the levels of SP-A, SP-D and those of fucose in BL recovered from patients with asthma was also analysed. Only the level of SP-A correlated strongly with those of fucose in patients with bronchial asthma ( $\mathrm{r}=0.849, \mathrm{p}<0.01$ (fig. 4)).

\section{Discussion}

It has been demonstrated that there is increased amounts of SP-A in both the BL, which would be enriched with the components in the airway, and in the AL, which would mainly represent the components in the alveolar spaces in patients with bronchial asthma [10]. Although the increase in SP-D in the AL was associated with that in SP-A, SP-D in BL was not. To the best of the authors knowledge, this is the first study to analyse the amount of surfactant proteins in the airways separately from those in the alveolar spaces.

The precise mechanism for the increase in SP-A levels but not SP-D in the BL in patients with asthma is still unknown. It was also demonstrated that the SP-A levels in the BL strongly correlated with those of fucose, which is thought to be a marker of airway secretion. Mucus hypersecretion in the airways is one of the characteristics of the pathogenesis of bronchial asthma. In the human lung, submucosal glands are only found in the large cartilaginous airways and it is usually assumed that the submucosal glands secrete most of the mucus in human airways. The transgenic mice in which interleukin (IL)-4 was expressed in the bronchial and bronchiolar epithelial
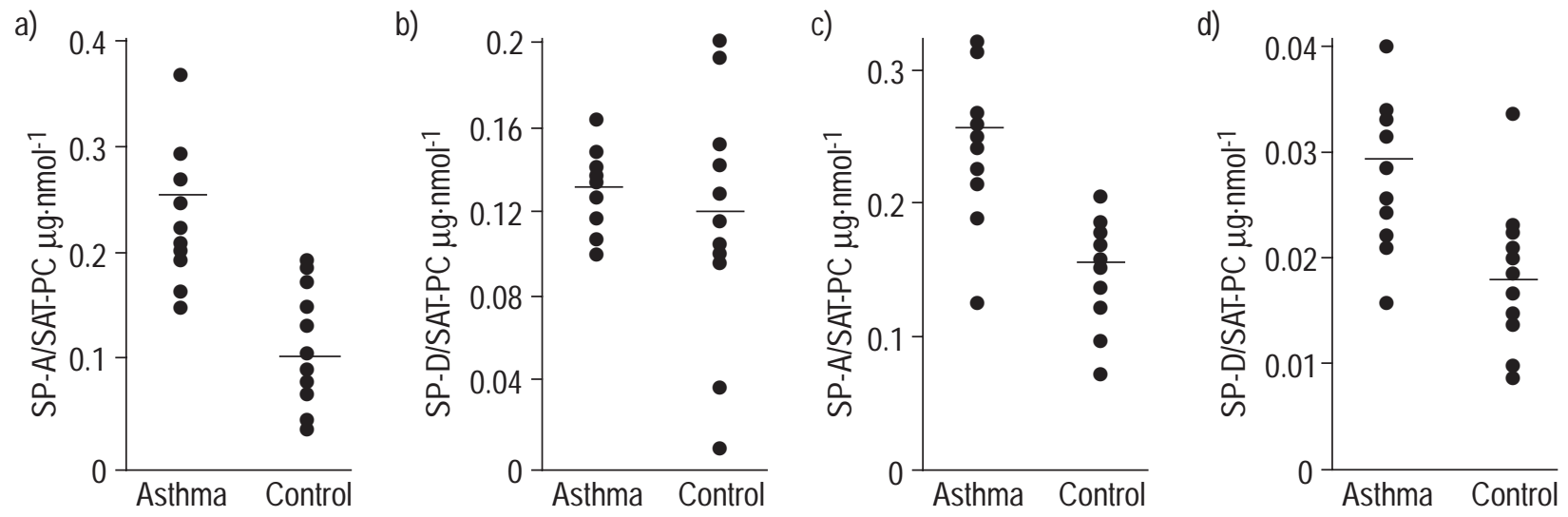

Fig. 3. - The ratios of surfactant protein A (SP)-A, surfactant protein (SP)-D, to saturated phosphatidylcholine (SAT-PC) in bronchial lavages (BL) (a) and (b) respectively, and alveolar lavages (AL) (c) and (d) respectively. p<0.05 for (a), (c) and (d) and was not significant for (b). 


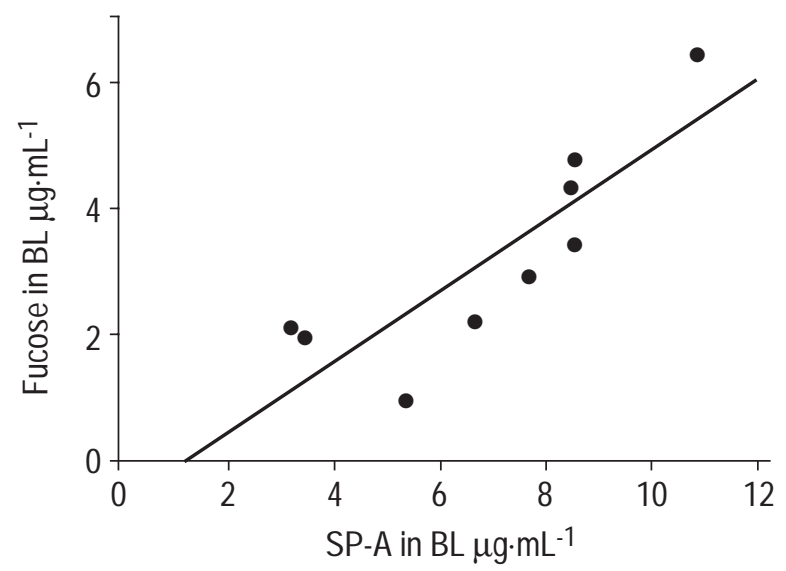

Fig. 4. - Correlation between the levels of surfactant protein (SP)-A, surfactant protein (SP)-D and fucose in bronchial lavages (BL) recovered from patients with asthma. The levels of SP-A closely correlated with those of fucose in patients with bronchial asthma $(r=0.849, p<0.01)$.

cells also showed increased concentrations of SP-A and SP-B in lung homogenates and BAL fluid [19]. If all the findings are considered together, the increase in SP-A, which was correlated with that of fucose, may reflect the selective secretion of SP-A in the submucosal glands by allergic inflammation. Further studies will be needed to clarify how SP-A and mRNA levels of SP-A would be regulated in the airway submucosal glands. The observations in this study also suggested that SP-A and SP-D might be regulated in a different manner in the airways from that in the alveoli.

Several recent studies have shown that SP-A and SP-D have the capacity to modify the secretion and production of cytokines, and proliferation in various inflammatory cells $[19,20]$. WANG et al. [21] reported that SP-A and SP-D were able to suppress allergen-induced lymphocyte proliferation and histamine release in children with asthma in a stable condition. Suppressive effects of SP-A on ionomycin-induced interleukin (IL)-8 production and release by eosinophils was also found in an earlier study of the authors [22]. Increased levels of SP-A in the airways and in asthmatics could reflect the anti-allergic inflammatory mechanisms in the pathogenesis of asthma. Furthermore, SP-A is known to play an important role in the host defence with alveolar macrophage interaction and to enhance the phagocytosis of a number of microbial species, including bacteria and viruses $[5,6]$. It can be speculated that the increased SP-A levels in the airways play a role both in suppressing an allergic inflammation and in the host defence of airways.

High levels of SP-A and SP-D in the AL were also found. McInTosh et al. [23] reported that SP-A and SP-D levels in the BAL fluid and the mRNAs of SP-A and SP$\mathrm{D}$ in the lung tissues were increased by intratracheal lipopolysaccharide (LPS) instillation in rats. KRAFT et al. [24] recently studied chronic asthma patients with/ without nocturnal asthma by comparing proximal airway endobronchial tissue with distal alveolar tissue, they found that eosinophils and macrophages accumulated to a greater extent in the alveolar tissue, and these changes contributed more to the variation in lung function than inflammation in the more proximal tissue. Recent autopsy studies also [25] suggest that the pathological changes seen in asthma occur in the alveolar area as well as in the airways. The altered surfactant composition in the AL might also result from the inflammation in type II cells. The involvement of alveolar inflammation in the pathogenesis of bronchial asthma could be studied from the view of the surfactant alteration.

VAN DE GRAAF et al. [26] previously reported that SP-A in BAL fluids was decreased in patients with bronchial asthma. The subjects in their study were chronic and stable asthmatics, which were similar to those in the present study. The treatments for bronchial asthma were also similar. It would be hard to explain this discrepancy by the difference between ethnic groups. The only difference in their study was the technique employed for bronchoalveolar lavage. They performed BAL with seven $20 \mathrm{~mL}$ aliquots of saline, whereas three consecutive lavages with $50 \mathrm{~mL}$ saline were used in the present study. They did not analyse the first two aliquots, which the present study used as BL for the SP-A analysis. The authors found higher levels of SP-A in the AL in the present study. HockeY et al. [27] also reported in an abstract that the mean ratio of SP-A to total phospholipid in BAL and sputum samples was much greater in asthmatic subjects than in controls and there was a tendency for SP-D to be high. These data were also comparable with this study.

The concentration of SP-A or SP-D did not correlate with pulmonary functions in asthmatics, including $\mathrm{VC} \%$, FEV1\%, V50 and V25 (data not shown). One explanation would be the fact that SP-A and SP-D are not critical for maintaining the surface properties. Even the decreased ratios of SAT-PC to total proteins in BL and AL did not reflect the pulmonary functions. Another possible explanation is that the condition of the study subjects was too mild and stable to show an association between surfactant function and pulmonary functions.

To conclude, increased amounts of surfactant protein A in the bronchial lavages and alveolar lavages were found. A high concentration of surfactant protein $\mathrm{D}$ was also found in the alveolar lavages. The high levels of surfactant protein $\mathrm{A}$ in the bronchial lavage fluids correlated with those of fucose, which is one of the markers of airway secretion. The observations suggested that surfactant protein A may be secreted from the airways in a different manner from the alveoli, and the surfactant protein A secretion might be stimulated by allergic inflammation. The increased levels of surfactant proteins A and D may play a protective role in both host defense and in an allergic inflammation in the pathogenesis of bronchial asthma.

\section{References}

1. Lye M, Wang L, Li E, Enhorning G. Pulmonary surfactant will secure free airflow through a narrow tube. $J$ Appl Physiol 1991; 71: 742-748.

2. Kurashima K, Ogawa H, Ohka T, Fujimura M, Matsuda T, Kobayashi T. A pilot study of surfactant inhalation in the treatment of asthmatic attack. Jpn J Allergol 1991; 40: $160-163$.

3. Liu M, Wang L, Enhorning G. Surfactant dysfunction develops when the immunized guinea-pig is challenged with ovalbumin aerosol. Clin Exp Allergy 1995; 25: 1053-1060. 
4. Kurashima K, Fujimura M, Matsuda T, Kobayashi T. Surface activity of sputum from acute asthmatic patients. Am J Respir Crit Care Med 1997; 155: 1254-1259.

5. Tenner AJ, Robinson SL, Borchlet J, Wright JR. Human pulmonary surfactant protein (SP-A), a protein structually homologous to Clq, can enhance FcR- and Clq-mediated phagocytosis. J Biol Chem 1989; 264: 13923-13928.

6. Kuan SF, Rust K, Crouch E. Interactions of surfactant protein D with bacterial lipopolysaccharides: surfactant protein D is an Escherichia colibinding protein in bronchoalveolar lavage. J Clin Invest 1992; 90: 97-106.

7. Bernhard W, Haggsman HP, Tschering T, et al. Conductive airway surfactant: surface-tension function, biochemical composition, and possible alveolar origin. $A m J$ Respir Cell Mol Biol 1997; 17: 41-50.

8. Wong CJ, Akiyama J, Allen L, Hawgood S. Localization and developmental expression of surfactant proteins D and $\mathrm{A}$ in the respiratory tract of the mouse. Pediatr Research 1996; 39: 930-937.

9. Saito H, Okayama H, Shimura S, Fushimi T, Masuda T, Shirato K. Surfactant protein A2 gene expression by human airway submucosal gland cells. Am J Respir Cell Mol Biol 1998; 19: 202-209.

10. Rennard SI, Ghafouri MO, Thompson AB, et al. Fractional processing of sequential bronchoalveolar lavage to separate bronchial and alveolar samples. $\mathrm{Am}$ Rev Respir Dis 1990; 141: 208-217.

11. Fukuda T, Fukushima Y, Numao $\mathrm{T}$, et al. Role of interleukin-4 and vascular cell adhesion molecule-1 in selective eosinophil migration into the airways in allergic asthma. Am J Respir Cell Mol Biol 1996; 14: 84-94.

12. Bartlett GR. Phosphorus assay in column chromatography. J Biol Chem 1958; 234: 466-468.

13. Bligh EG, Dyer WJ. A rapid method of total lipid extraction and purification. Can J Biochem Physiol 1959; 37: 911-917.

14. Mason RJ, Nellenbogen J, Clements JA. Isolation of disaturated phosphatidylcholine with osmium tetroxide. $J$ Lipid Res 1978; 17: 281-284.

15. Shimizu H, Hosoda K, Mizumoto $\mathrm{M}$, et al. Improved immunoassay for the determination of surfactant protein A (SP-A). Tohoku J Exp Med 1989; 157: 269-278.
16. Honda Y, Kuroki Y, Matuura E, et al. Pulmonary surfactant protein D in sera and bronchoalveolar lavage fluids. Am J Respir Crit Care Med 1995; 152: 1860-1866.

17. Lowry OH, Rosebrough NJ, Farr AL, Randall RJ. Protein measurement with the folin phenol reagent. $J$ Biol Chem 1951; 193: 265-271.

18. Winzler RJ. In: Glick D, ed. Methods of Biochemical Analysis. Vol II. New York, Interscience Publisher, 1955; pp. 279-311.

19. Jain-Vora S, Wert SE, Temann UA, Rankin JA, Whitsett JA. Interleukin-4 alters epithelial cell differentiation and surfactant homeostasis in the postnatal mouse lung. Am J Respir Cell Mol Biol 1997; 17: 541-551.

20. Borron P, Veldhuizen RAW, Lewis JF, et al. Surfactant associated protein A inhibits human lymphocyte proliferation and IL-2 production. Am J Respir Cell Mol Biol 1996; 15: 115-121.

21. Wang JY, Shieh CC, You PF, Lei HY, Reid KBM. Inhibitory effect of pulmonary surfactant proteins $\mathrm{A}$ and $\mathrm{D}$ on allergen-induced lymphocyte proliferation and histamine release in children with asthma. Am J Respir Crit Care Med 1998; 158: 510-518.

22. Cheng G, Ueda T, Nakajima H, et al. Suppressive effects of SP-A on ionomycin-induced IL-8 production and release by eosinophils. Int Arch Allergy Immunol 1998; 117: S59-S62.

23. McIntosh JC, Swyers AH, Fisher JH, Wright JR. Surfactant Proteins A and D increase in response to intertracheal lipopolysaccharide. Am J Respir Cell Mol Biol 1996; 15: 509-519.

24. Kraft M, Djukanovic R, Wilson S, Holgate ST, Martin RJ. Alveolar tissue inflammation in asthma. Am J Respir Crit Care Med 1996; 154: 1505-1510.

25. Hamid Q, Song Y, Kotsimbos TC, et al. Respiratory pathophysiologic responses inflammation of small airways in asthma. $J$ Allergy Clin Immunol 1997; 100: 44-51.

26. Van de Graaf EA, Jansen HM, Lutter R, et al. Surfactant protein A in bronchoalveolar lavage fluid. J Lab Clin Med 1992; 120: 252-263.

27. Hockey M, Mander A, Wang JY, Reid KBM, Djukanovic R, Postle AD. Pulmonary surfactant composition in asthma. Am J Respir Crit Care Med 1997; 155: A78. 